
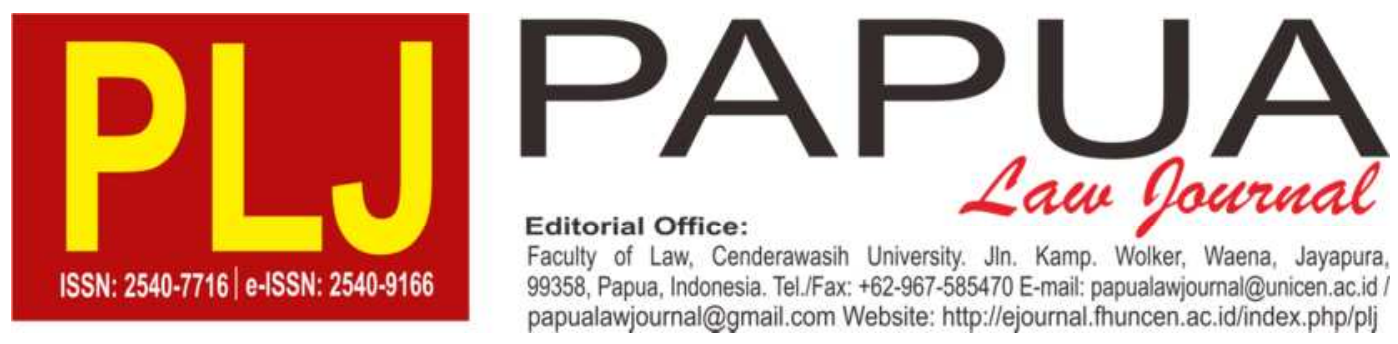

\title{
Local Election and Reinforcement Democracy in the Indonesian State System
}

\author{
Anthon Raharusun \\ Chief of Perhimpunan Advokat Indonesia (Peradi) of Jayapura City \\ Email: anthonraharusun@yahoo.co.id
}

\begin{abstract}
The direct election of Regional Head and Deputy Regional Head directly and democratically by the people is a political process of the Indonesian nation towards a more democratic, transparent, accountable and responsible political life and administration. Therefore, in order to ensure the implementation of election of Regional Heads and Regional Representatives at a time of quality and meet the degree of healthy competition, the requirements and procedures for election of Regional Head shall be stipulated in separate laws and regulations. In general it is said that the direct election of the regional head is more democratic. There are at least two reasons why the idea of direct election is considered necessary: First; to open the door for the appearance of the head of the region in accordance with the will of the majority of the people themselves. Second; to maintain government stability so as not to be easily dropped in the middle of the road. Practice during the regime of Law Number 22 Year 1999 regarding Regional Government, indicates that the election through DPRD mechanism is often opposed even not in accordance with the will of the majority of people in the region. In this connection, there are several reasons why the direct Election of Regional Head (Local Election) is important for the development of democracy in Indonesia are: First; direct regional head elections allow for the strengthening of democracy at the local level, in particular the development of political legitimacy. This is based on the assumption that the elected Head of Region has a strong mandate and legitimacy, because it has the support of the people's voice directly reflecting the configuration of political forces and the interests of the constituents of voters. This legitimacy is very important for the governing government. Second; Direct Regional Head Election is expected to be able to build and realize local accountability and strengthening of democratic values in Indonesian state administration system.
\end{abstract}

Keywords: Local Election; Strengthening; Democracy and State System. 


\section{INTRODUCTION}

The dynamics of state administration in Indonesia is growing in line with the dynamics of the amendment to the 1945 Constitution of the State of the Republic of Indonesia (the 1945 Constitution of the Republic of Indonesia). Theoretically, the change and change of a constitution can be seen as part of a process of constitutional improvement as a result of the dynamics of changes in the political system of law and democratization. Efforts to perfect the inner deficiencies contained in a constitution, according to K.C. Where can be done through formal amendment, constitutional convention, or judicial interpretation ${ }^{1}$. Along with this, the improvement and amendment of the 1945 Constitution of the Year 1945 both the first ${ }^{2}$, second ${ }^{3}$, third ${ }^{4}$ and fourth $^{5}$ (even fifth) amandement are expected to create and oversee the political transition of authoritarianism into the era of constitutional democracy as an effort to create a democratic

\footnotetext{
${ }^{1}$ K.C. Wheare, 2003 Konstitusi-Konstitusi Modern, First Publish, Published by Pustaka Eureka, Surabaya, p. 1.

${ }^{2}$ First Amandment, 1999

${ }^{3}$ Second Amandent, 2000

${ }^{4}$ Third Amandment, 2001

${ }^{5}$ Fourth Amandment, 2002
}

government both at the national level (central government) and at the subnational level (local government).

In the reform era there emerged a mass of aspirations and strong lawsuits in order that the elections as the most obvious means for the implementation of democracy should be held in a direct, public, free, secret, honest and fair manner. In the 1999 election we may rejoice because it has successfully held a fair and clean relatif, especially when compared with the New Order era elections. Although it must be acknowledged at the level of the Indonesian Electoral Committee that was filled with political parties, there was confusion in the determination of the election results, but public commonsense stated that the 1999 election was the best election after the first election of 1955. But the problem or the threat to improved elections has emerged since the 2004 legislative elections, then strengthened again in the 2009 elections, mainly related to money politics and the strengthening of oligarchy among political parties. The problem is not conducive, even democracy, this can be seen from various cases that are published naked in various mass media and become a 
case of dispute over election result and regional head election in the Constitutional Court. In addition, other issues that often occur in general elections, legislative elections, presidential and vice presidential elections and local elections are related to inaccurate voters list (voter list), manipulation in vote count and recapitulation of vote count results, neutralization of organizing institutions , and various other issues related to the implementation of the Election.

The Election is a minimum requirement of the implementation of a democratic system, in which the highest collective decision-makers in the system are chosen through an honest, fair and regular mechanism. Josner Simanjuntak, a Constitutional Law Expert of Cenderawasih University in one of his articles argues that One of the mainstream of the reform era is to strengthen the process of democratization in the form of national and statehood arrangement in accordance with the principles of democracy or more often referred to as the consolidation of democracy through the implementation of democratic elections. Therefore, in the historical development of modern states, elections are regarded as a milestone for the upholding of the democratic system. Linking elections to democracy can actually be seen in simple relationships and formulas so that some say that elections are one of the most obvious forms and ways of implementing democracy. If democracy is defined as a government of, by and for the people, then the way of the people to determine the government is done through elections. This is necessary because in this modern age there is no direct democracy or democracy that the entire people of the times of the poles in ancient Greece about 2,500 years ago ${ }^{6}$. In modern democracies, elections are always associated with the concept of representative democracy or indirect democracy, which means that the participation of the people in government is done by people's representatives who are directly elected by the people directly, so that the election results should reflect the configuration streams and political aspirations that live in the midst of the people. Such a concept and

\footnotetext{
${ }^{6}$ Jenedjri M. Gaffar, 2012 Politik Hukum Pemilu, First Publish, Published by Konstitusi Press, Jakarta, p. xiv.
} 
understanding also underlies the conduct of elections throughout the history of the Unitary State of the Republic of Indonesia.

There are several reasons why elections are important to a democratic country. First, through elections can be built the basis and concept of democracy. Without elections, without open competition between social forces and political groups, there is no democracy. Second, elections legitimize the political system. Third, endorse political leadership. Fourth, the election as a key element of political participation in democracies. Therefore, the dynamics of the implementation of regional head elections is a manifestation and the realization of the political and democratic rights of the people to determine the course of government and state administration as mandated in the 1945 NRI Act. In addition, the election of regional heads is also intended to measure the level of support and public confidence against a leader.

Related to the above mentioned reasons, in connection with the election, especially the election of regional head (Pilkada), then some things to note related to the direct election of direct regional head are: First; direct regional head elections allow for the strengthening of democracy at the local level, in particular the development of political legitimacy. This is based on the assumption that the elected Head of Region has a strong mandate and legitimacy, because it has the support of the people's voice directly reflecting the configuration of political forces and the interests of the constituents of voters. This legitimacy is very important for the governing government. Second; Direct Regional Head Election is expected to be able to build and realize local accountability and strengthening of democratic values in Indonesian state administration system.

Juridically, the basis for the implementation of the election of the Head of Region is conducted democratically (directly) can be found in the provisions of Article 18 paragraph (4) of the 1945 Constitution of the Republic of Indonesia states that "Governors, Regents and Mayors respectively as Head of Provincial, and City is elected democratically". If we look at the constitutional mandate, then 
the election of the regional head is not explicitly stated as to whether the election of the regional head includes the election of the Vice Governor, Vice Regent and Deputy Mayor elected democratically in one pair of candidates for Regional Head and Deputy Regional Head. However, after the issuance of Law Number 32 Year 2004 regarding Regional Government then interpreted included in it is the governor, regent, and mayor have a partner of a representative who also selected as a candidate pair. This matter has been affirmed in the provision of Article 56 of Law Number 32 Year 2004 stipulated that the regional head and deputy head of region shall be elected in one candidate pair which is carried out democratically based on the principle of direct, public, free and secret, honest and fair. The pair must be submitted by a political party or a coalition of political parties as well as in presidential and vicepresidential elections.

Local election of Regional Head and Deputy Regional Head directly and democratically by the people is a political process of Indonesian nation towards a more democratic, transparent, accountable and responsible political life. Therefore, in order to ensure the implementation of election of Regional Heads and Regional Representatives at a time of quality and meet the degree of healthy competition, the requirements and procedures for election of Regional Head shall be stipulated in separate laws and regulations. In general it is said that the direct election of the regional head is more democratic. There are at least two reasons why the idea of direct election is considered necessary: First; to open the door for the appearance of the head of the region in accordance with the will of the majority of the people themselves. Second; to maintain government stability so as not to be easily dropped in the middle of the road. Practice during the regime of Law Number 22 Year 1999 regarding Regional Government, indicates that the election through DPRD mechanism is often opposed even not in accordance with the will of the majority of people in the region.

The disadvantages of Law Number 22 Year 1999 have been realized by the representatives of the people who sit in MRP-RI, thus giving rise to MPR Decree No. IV/MPR/2000 on Policy 
Recommendation in the Indonesia has been refined and

Implementation of Regional

Autonomy. At the same time, in the

Annual Session of the MPR-RI of 2000, there has been a second amendment of the 1945 Constitution of the Republic of Indonesia, which among others has changed Chapter IV on Regional Government with Article 18, Article 18 letter A and Article 18 letter B so that the MPR Decree No. IV/MPR/2000 is in line with the amendment of the 1945 Constitution of the Republic of Indonesia.

One point of the recommendation states that: in line with the spirit of decentralization, democracy and equality of central and local relations, it is necessary to initiate a fundamental revision of Law Number 22 Year 1999 on Regional Government. The revision is intended as an effort to adjust to Article 18 of the 1945 Constitution of the Republic of Indonesia of the 1945 Constitution on the basis of the mandate of the MPR TAP above, the need to revise Law No. 22 of 1999, inevitably, especially Article 18 of the 1945 Constitution of the Republic of Indonesia, which became its basis, after the second amendment of the 1945 Constitution of the Republic of augmented to become clearer and more detailed. On the other hand, the regulation of regional head election based on Law Number 32 of 2004 on Regional Government contains a number of weaknesses both in terms of system and technical rules.

In the context of the implementation of political decentralization, Indonesia has now conducted direct election of regional head (pilkada) which started on 1 June 2005 as a manifestation of efforts to strengthen regional democratization agenda ${ }^{7}$. However, the implementation of the policy of political decentralization has generated considerable political dynamics in the period 2005-2014, in which the implementation of the Pilkada brought negative implications on the one hand, namely bringing the potential for the absence of effective and efficient local government administration, as well as triggering conflicts horizontally ${ }^{8}$. Therefore, based on the background of various problems that exist and the

\footnotetext{
7 Info Seputar Otonomi Daerah (Info Otda), "Menata Pilkada Kita" Edisi 3/September-Desember, Jakarta, Dirjen Otda, 2011, p.3.

${ }^{8}$ Ibid.
} 
understanding that the implementation of regional head elections as regulated in the Law on Regional Government is not in line with the demands of current contemporary democracy, the regulation on the Election of Regional Head needs to be regulated in a separate law. In relation to the regulation of Regional Head Elections in this Law, the DPR-RI has ratified Law no. 8 of 2015 on Amendment to Law No. 1 of 2015 on Stipulation of Government Regulation in Lieu of Law No. 1 of 2014 on the Election of Governors, Regents, and Mayors Becoming Law). This law, among others, is directed to project an ideal future Pilkada format, as well as to place elections consistently in the Indonesian state administration by restructuring the Chief Election mechanism Regions simultaneously in Indonesia with various socio-political dynamics in its implementation ${ }^{9}$.

\footnotetext{
${ }^{9}$ Election simultaneously in Papua will be implemented in 11 regencies, among others include: (1). Keerom Regency; (2)Mamberamo Raya Regency; (3) Waropen Regency; (4) Supiori Regency; (5) Nabire Regency; (6). Yalimo Regency; (7) Yahukimo Regency; (8) Pegunungan Bintang Regency; (9) Asmat Regency; (10) Boven Digoel Regency; and (11) Kab. Merauke. While in the Province of West Papua there are 9 regencies that will implement local election, among others: (1) Sorong Selatan Regency; (2) Raja Ampat Regency; (3) Fak-fak Regency; (4). Kaimana
}

Therefore, local elections in addition to the means to strengthen democracy at the local level is also a mechanism to create local governments that are capable of creating accountability and effectiveness of local governance, equality of citizens' rights in policing and for strengthening national democracy ${ }^{10}$. In addition, one of the objectives of the local election to be held in conjunction with the election of governors, regents, mayors is to create effectiveness and efficiency of the state budget. For example, the election of the Governor in conjunction with the election of the Regent or Mayor, the financing of TPS officers only needs to be paid once including the cost of technical guidance, socialization costs, and other expenses for a one-time financing, including the process of

Regency; (5) Teluk Bintuni Regency; (6) Teluk Wondama Regency; (7) Manokwari Regency; (8) South Manokwari Regency; and (9) Arfak Mountains Regency.

${ }^{10}$ Direct elections on December 9, 2015 will be held in 269 regencies / cities consisting of 9 provinces, 36 cities and 224 districts. Implementation of Pilkada will be conducted simultaneously in three stages. The first phase on December 9, 2015, for heads of regions and deputy heads of regions that entered the end of term (AMJ) 2015 and first semester 2016. The second phase is done in February 2016 for AMJ second semester of 2016 and 2017. The third phase was held in June 2018 areas that AMJ 2018 and 2019. Gradually, the Pilkada Serentak will be used as a pilkada model simultaneously in 2027. 
recapitulating the election of the governor, counting the votes of regents, mayors. In relation to the efficiency of this budget, the KPU (Komisi Pemilihan Umum/ National Election Comitte) also imposes restrictions on campaign expenses. Restrictions are made by taking into account the campaign method, the number of activities, the estimated number of participants, the regional cost standards, the necessary campaign materials, the coverage area and the geographical conditions, logistics and campaign management. This is done by the KPU so that the candidates for regional head are expected not to be stuck with money politics ${ }^{11}$. Another problem that is of major concern to the KPU in the implementation of the local elections is related to socialization. For participation electorate of national election has been tipping point, especially in a number of big cities in Indonesia such as Medan, Surabaya and Bandung. Related to this socialization according to the KPU, there are at least three methods that will be used for socialization activities,

${ }^{11}$ Majalah Suara KPU, "Agar Kampanye Tak Mengalami Distorsi”, Edisi II, MaretApril 2015, p. 64. ie mass communication such as face to face, limited meetings, discussions; advertising in print, electronic, social media and socialization through various networks owned by KPU.

Based on the above description, the fundamental question in this paper focuses on: First: What are the problems that often occur in the implementation of regional head elections in Indonesia. Secondly: will elections simultaneously strengthen democracy within the Indonesian state administration system? and is the Pilkada (local election) at the same time a moment of consolidation of the Pancasila democratic system?

Therefore, before the author elaborates or discusses more about this article, it first discusses some theories relevant to the topic of discussion in this writing, especially on how the theoretical relationship between political parties in a democratic country with the democratic process itself (read: elections), including how the establishment of good legislation.

\section{Political Parties and Democratic Theory}

The party in the process of democracy is as a very strategic bridge for the processes of governance with 
citizens. In fact, many argue that a political party that actually determines democracy, as Schattscheider (1942) put it in Jimly Asshiddiqie ${ }^{12}$ "political parties created democracy". Therefore, political parties are very important pillars for the workings of the political system and democracy. Even Schattscheider says, "Modern democracy is unthinkable save in terms of the parties". However, many still provide critical and even skeptical views of political parties. The most crucial of them is that the political party is actually nothing more than a political vehicle for a ruling elite.

In a democratic country, the position and role of every state institution must be equally strong and mutually controlling in the "check and balances" relationship. However, if these institutions are not functioning properly, their performance is ineffective or weak in their respective functions, it is often the greedy or extreme political parties that are rampant in controlling and controlling all the processes of functioning government functions. Therefore, a

12 Jimly Asshiddiqie, 2006 Kemerdekaan Berserikat Pembubaran Partai Politik dan Mahkamah Konstitusi, Cetakan Ketiga, Penerbit Konstitusi Press, Jakarta, p.52. good party system will determine the functioning of the state administration system based on the principle of check and balances in a broad sense. In contrast, the effective functioning of the state's institutional functions in accordance with the principle of check and balances under the constitution also greatly determines the quality of party systems and the mechanisms of democracy developed in a country. All of this is certainly closely related to the dynamics of the growth of tradition and culture of free thinking in the life of nation and society. This tradition of thought or freedom of thought in turn influences the growth of the principles of freedom of association and assembly in the dynamics of the life of democratic societies. In this connection, according to Clinton Rossiter ${ }^{13}$ that, "there is no democracy without politics, and no political without party". This Rossiter axiom has been applied by political scientists to governments in various countries of the world (including Indonesia). Thus, the

13 Clinton Rossiter, Parties and Party Politics in Amerika, Ithaca, NY: Cornell University Press, 1960, page.1. See Richard S. Katz dan William Crotty, Hand Book of Party Politics, London: SAGE Publications, 2006, p. 7. 
Political Party is very important for a democratic government. Political Parties become an important liaison in any society with the highest power contested through elections.

The process of institutionalization of democracy is basically highly determined by the institutionalization of political party organization as an integral part of the democratic system itself. Therefore, according to Yves and Andrew Knapp ${ }^{14}$, A democracy system without political parties or with a single party is impossible or at any rate hard to imagine ". A system with only 1 (one) political party, it is difficult to imagine to be called democratic, especially if without a political party at all. The level and degree of institutionalization of political parties themselves in the democratic system, further according to Yves Meny and Andrew Knapp, depends on 3 (three) parameters, namely (i) his age, (ii) the depersonalization of organization, and ) "Organizational differentiation". Every normal organization grows and develops naturally according to its own timeline. Therefore, the older age, ideas

14 Yves and Andrew Knapp, 1998., Governmental and Politics in Western Europe: Britain, France, Italy, Germany, Third Edition, Oxford Universiy Press, p. 86. and values adopted within the organization are increasingly institutionalized into a tradition within the organization (read: political party). In this connection, a structured and institutionalized political party can maintain its existence in the face of various changes in political and constitutional systems without having to abandon its identity and deform, some merger, (splinter).

Moving from the existence of political parties, in general ordinary political scientists describe the existence of 4 (four) functions of political parties. The four functions of the political party according to Mirian Budiardjo $^{15}$ include: (i) political communication facilities, (ii) political socialization, (iii) political recruitment facilities, and (iv) conflict management, . In terms of Yves Meny and Andrew Knapp ${ }^{16}$, the functioning of the political party includes the functions of (i) mobilization and integration, (ii) means of forming influence on voting patterns; (iii) means of political recruitment, and (iv)

\footnotetext{
${ }^{15}$ Mirian Budiardjo, 2000 Pengantar Ilmu Politik, Gramedia, Jakarta, p. 163-164

16 Yves and Andrew Knapp, 1998., Governmental and Politics in Western Europe: Britain, France, Italy, Germany, Third Edition, Oxford Universiy Press, p. 86.
} 
means of elaboration of policy options. The four functions are equally related to one another. As a means of political communication, the party plays a very important role in articulating the interests or interests of the existing or sometimes hidden political interests in society.

According to Brian C. Smith and Robert Dahl mentions that local accountability, political equiry, and local responsiveness are at stake in every region. All three betting is a benchmark to see how far the government in the area run effectively. To strengthen democracy at the local level, local elections are a mechanism to create local governments that are capable of creating accountability in their regions, equal citizens' rights in politics and strengthening local democracy (read: local government).

\section{Election Theory}

As mentioned above, that there are several reasons why elections are important for a democratic country? First, through elections can be built the basis and concept of democracy. Second, elections legitimize the political system. Third, endorse political leadership. Fourth, the election as a key element of political participation in democracies. Therefore, from the point of view of electoral theory has a meaning as one of the means for an important instrument for democracy. The rights and obligations of the people known as the right on candidate and the right to be vote to participate in the elections have been regulated in the 1945 Constitution of the Republic of Indonesia, as well as in international conventions. The State has the authority to limit the participation or participation of citizens to the extent that it is not contrary to the norms laid down in the Constitution. With as much as possible does not contain elements of discrimination and does not create different treatment to every citizen of Indonesia. States may restrict citizens under certain conditions to participate, for example in cases of incompetence, whether underage or mentally disturbed, or in the case of a judicial verdict that deprives a citizen of his or her right, choose. Other restrictions are permitted to the extent that they meet the requirements set forth in Article 28J paragraph (2) of the 1945 Constitution of the Republic of Indonesia, namely that constitutional restrictions are intended solely to 
secure the recognition and respect of the rights and freedoms of others, and to fulfill fair demands. However, such restrictions are bound to the four elements; moral, religious values, security, and public order.

\section{Theory of the Legal Drafting}

John Locke argues that legislation created by legislative powers is a law that can give the public goodness (make them for the public good) or contain elements of public interest ${ }^{17}$. The soul of the statesman must be possessed by the holder of this power, prioritizing the interests of the people. If it is not necessarily able to give consequences because the law will be a juridical basis in the administration. Further, according to VCRAC Crabbe, the most important aspect of legislation is not only regulatory aspects but also the process of making it (the important part of legislation is not only the regulatory aspect but the law-making process itself) ${ }^{18}$. The process of

17 Bayu Dwi Anggono, Perkembangan Pembentukan Undang-Undang di Indonesia, Jakarta, Konstitusi Press, 2014, p. 12. See John Locke, Two Treaties of Civil Government, dalam MDA Freeman, Introduction to Jurisprudence, seventh ED, (London: Sweet \& Maxwell Ltd, 2001), p.150.

18 VCRAC Crabbe, Legislative Drafting. London: Cavendish Publishing Limited, 1994, p. 4. making/forming a law needs to be guided by the principles or principles of the formation of a good law due to two reasons, namely first, the existence of public demands directed to the legislator against the law that is produced that is, ; can be upheld; in accordance with the principles of legal guarantees and equality of regulated target rights; and able to absorb people's aspirations ${ }^{19}$; and secondly, considering its function in improving the quality of the law so that the resulting legislation has effectiveness in terms of achieving the objectives, implementation and enforcement of the law $^{20}$. While the effectiveness of law according to Hans Kelsen is that people actually do according to the norms of law or in other words the norms are actually applied and obeyed ${ }^{21}$. making / forming of local government law and election law of governor, regent and mayor during the reign of Susilo Bambang Yudhoyono (SBY) which

${ }^{19}$ Saifudin, 2009.,Partispasi Publik dalam Pembentukan Peraturan Perundang-undangan, Yogyakarta, FH UII Press, p. 2.

20 Yuliandri, Asas-Asas Pembentukan Peraturan Perundang-undangan yang Baik, Gagasan Pembentukan Undang-Undang Berkelanjutan, Jakarta, RajaGrafindo Persada, 2009, p. 252.

${ }^{21}$ Hans Kelsen, 1973 General Theory of Law and State, Translated By Anders Wedberg. New York: Russel\&Russel, p. 47. 
then continued and ratified during the reign of Joko Widodo.

Starting from the above discussions, according to the authors of the prospect of the implementation of elections in the future in democratic political life and democratization in the state administration system in Indonesia is to restore the entity of Indonesian democratic culture on Pancasila democracy as the main foundation that can function and able to maintain local and national political stability and create an effective, strong, accountable government with a high degree of legitimacy built on Pancasila ideology and values.

Based on the above mentioned question, the following will be described or discussed about how the problem of simultaneous elections in Indonesia and whether elections simultaneously can strengthen democracy in the Indonesian state administration system.

\section{METHODS OF THE RESEARCH}

The type of research is normativelegal research, which is used to study the rules of law or legal provisions with emphasis on the principles of law that relating to the Local Election System, especially related to the interaction between them.

The technique of data collection used is literature study, by studying various legal materials includes primary, secondary, and tertiary in accordance with the object of study. Data analysis is done by analyzing qualitative data by reducing data, presenting data and drawing conclusion.

\section{ANALYSIS AND DISCUSSION}

\section{Pilkada (local election) Problem in Indonesia}

After being held for the first time since 2005, electoral election (election) has not succeeded in giving birth or bring up a qualified regional head. This indicates that the election of regional heads not only gave birth to new leaders of the people's choice, but also gave birth to a myriad of new problems. The increasingly massive practice of money politics, conflicts, disputes, and even unrest always overshadows the implementation of elections. Indeed, this condition does not occur in all regions, because there are heads of regional election results that successfully lead the region. However, if we look at data that since 2004, hundreds of heads of regions and 
former heads of regions have become suspects or criminals in various corruption cases that are increasing every year. This is certainly a problem in the implementation of local governance so that Pilkada needs to be addressed comprehensively. In addition, the amount of costs to be incurred to become head of the region allegedly became one of the base terseretnya regional heads in the vortex of budget lapses. The problem of the increasingly stern Pilkada then by the Ministry of Dalan Affairs - taking the initiative to arrange Pilkada through Pilkada simultaneously as the entrance to organize the system of Pilkada implementation thoroughly so that it is much better and efficient. The electoral rules that have been entrusted in the Law on Regional Administration (Undang-Undang Nomor 32 Tahun 2004) are not able to answer the challenges and problems of the increasingly complex elections. For this reason the government has issued Law No. 8 of 2015 on the Amendment of Law No. 1 of 2015 on Stipulation of Government Regulation in Lieu of Law No. 1 of 2014 on the Election of Governors, Regents, and Mayors. With this new shrimp, it is expected that
Pilkada can be more advanced, better, and more perfect, can even reduce and eliminate all problems that arise in Pilkada, considering one of the biggest problems in the implementation of Pilkada so far is not succeeded in giving birth and bring up leader of regional heads with integrity, quality, free of corruption. Other issues, "Pilkada" costs are too high (costs of organizing and expenses to be paid to candidates), politicization often occurs in bureaucratic positions, increasingly massive money politics practices, and many other issues. This is what then led to the implementation of local government does not run effectively.

Moving from various problems in the implementation of democracy in Indonesia, it is necessary to take various consolidation steps in democracy. Consolidation of democracy is a dynamic effort that needs to be done continuously to improve the quality of democracy (read: election/pilkada). At least, today we are faced with three social phenomena that necessitate an evaluation of the system, culture, and democratic rules. First, the democratic system in the context of the election of regional heads that depend on the 
sovereignty of the people does not always result in the head of the region acting according to the aspirations of the people. Second, the administration of government tends to be unstable, ineffective and tend to be politicized positions in the bureaucracy. Third, the run of democracy is not directly proportional to the improvement of people's welfare. This problem needs to be taken into consideration for the steps to improve and improve the electoral system itself in the context of Indonesian democracy, especially Pancasila democracy which is in accordance with the culture and ideology of the Indonesian nation.

In relation to the various Pilkada problems, there are at least some disappointing problems related to the implementation of the elections in Indonesia. First; Local elections are always accompanied by community conflicts, from the stage of candidacy and even post-election. Conflict is indeed a part of democracy, but the prolonged conflict and lead to violence and cessation of government certainly harm and injure the meaning of democracy itself, especially the meaning of Pancasila democracy in the Indonesian state administration system.
Second; money politics (money politics) is always "smell" in every election and has been regarded as a seasoning flavor. The real money politics is a bribery process (gratification) has shifted into fairness, both for the candidate and the community. In the New Order era, it is very possible also happened money politics, but then it is still done in secret. As a result of this money politics, the voice of the people become pale. The elected candidate is not necessarily the ideal candidate and desired by the people. Conversely, elected candidates pay more attention to their own interests than the interests of the people. Feeling that it has "bought" the voice of the people, there is no longer a relationship between to the elect and the voters. The sale is done.

Money politics resulted in the implementation of Pilkada to be very expensive for the candidate pair. In fact, in terms of implementation Pilkada certainly requires a more expensive cost compared with the election by the DPRD. Especially if it should be done in two rounds, as well as the possibility of re-voting based on 
the decision of the Constitutional Court (MK).

Third; there is bureaucratic politicization both ahead of elections and after elections. This resulted in chaos in the civil service world (PNS) in the region, where bureaucracy was forced by electoral politics to play tactics in the election so as to be neutral and professional. At the election after that, the employee who is considered to be impartial to the winning candidate will be dismissed from all positions, while those who are considered to be impartial will be given a position when they are not in accordance with their competence. Imagine how the government is managed on the basis of such a co-religionism. This is very serious and should not happen again in the future Pilkada, if the government consistently organize Pilkada is in the context of the future Pancasila democracy in the Indonesian state administration system.

Fourth, despite the direct election, it is not directly proportional to the improvement of prosperity and regional progress, including the progress of democracy. Not many regions have experienced significant improvements in welfare and progress. Some regions are indeed progressing quite phenomenally under the leadership of their regional head, but many more are on the way. In fact, some areas that have great economic potential and natural resources, was never progress.

Fifth; the facts show that in the era of decentralization / regional autonomy create new actors and modes of corruption in Indonesia $^{22}$. Local elections in no area without fraud. As a result, the elected regional heads have no impact on corruption eradication efforts. Instead of eradicating corruption, it turns out that many regional heads are involved in corruption cases, even many who have

22 Factors contributing to corruption in Indonesia are caused by: (i) integrity / morality related: corrupt behavior and behavior, consumptive and hedonic life behavior; (ii) structural factors: unbalanced economic structures and low incomes / salaries, the community's permissive attitude to corruption; (iii) Historical and political factors: the oligarchic structure controlled by the old elite, complicating reforms and the economy in Indonesia is still dominated by the same conglomerate, money politics to achieve and retain power; (iv) Decentralization / Regional Autonomy: Decentralization creates new actors and modes of corruption in Indonesia. Local elections in no area without fraud; (v) Quality of Regulation: in every regulation there must be a guarantee of legal certainty, because poor regulation will produce corrupt systems, on the contrary the quality of good regulation reduces the potential for corruption; and (vi) Law Enforcement: poor law enforcement quality will breed corruption, otherwise the quality of good and independent law enforcers is correlated with low levels of corruption. 
been thrown into prison or become convicted, both at the time of office and some time immediately after stepping down from office.

Sixth; special elections in Papua, especially some areas in mountainous areas, especially in Yalimo Regency; Yahukimo District and Kabupaten Pengunungan Bintang are still using noken as a substitute for the ballot box. The use of this voicemail box has been in progress since the decision of the Constitutional Court (MK) no. 47-48 / PHPU.A-VI / 2009, dated June 9, 2009 in a dispute over the Yahukimo District Election which permits the use of noken in voting in several areas in the mountains, among others in 10 (ten) districts respectively in Yahukimo district; Jayawijaya; Yalimo; Central Mamberamo; Tolikara; Lani Jaya; Nduga; Peak; Puncak Jaya; and Intan Jaya. While the other 19 (nineteen) districts in Papua (including 11 districts in West Papua) do not use this "system" of noken in elections (elections and legislative elections). Decision of the Constitutional Court in the election disputes in Yahukimo Regency that legalize the use of "noken" as a form of appreciation of cultural diversity in the pluralism of
Indonesia, so the decision of the Constitutional Court can not be dated or ditasirkan as a legal norm that gave birth to new legal norms that can be used as a legal product or legislation. Thus, the "noken system" as a culture can not be used as a democracy instrument permanently and continuously used in the context of elections in Papua or parts of Papua. the replacement of the ballot box is no longer necessary to be used as a model of democracy in the elections, both local elections and legislative elections in Papua (especially in cultural entities in the mountainous region). The use of noken, regarded as a setback in democracy and even the noken system can be considered to be destructive of the electoral system and not to educate the progress of a true democratic civilization even if placed in a violation perspective, this "noken system" can also be viewed as a structured, systematic and massif ${ }^{23}$.

\footnotetext{
${ }^{23}$ Structured violation means: the offense is committed through hierarchy of governmental power, involving government officials either at the provincial, regent or camat level. Disctrict heads, village heads or other government apparatus. Violation is Systematic, that is; deliberately planned through meetings, contacts that target certain voices, even through assignments carried out to commit acts that clearly violate the General Election, for example having the headman / village head or
} 
The six problems mentioned above give rise to the idea of improving the system and the way of local elections simultaneously according to the dynamics of democratic development and democracy (especially in Papua still using the "noken system"), local political contestation and growing governance. This change of local political constituency occurred when the House of Representatives agreed that the election of regional heads (Pilkada) simultaneously conducted in December 2015 and gradually elections will be held simultaneously until 2019 . In the end this nation managed to get out of political turmoil; a long debate about whether or not direct the election. The decision of the House of Representatives to conclude by stating that the elections are still held directly and simultaneously. Although the election of regional heads from time to time is still a problem, there is kesemrautan and indication of fraud in various lines. However, from various indications about the existence of fraud

someone assigned to contest all the ballot papers. While the violation is Massif, it means that the number of votes obtained is very fraudulent. If there is strong evidence of the three forms of violation, then the Constitutional Court may order the election to be repeated or the result is canceled. in the implementation of elections is a separate part of a political process. On the other hand, it can be seen as an advancement in our democracy because it becomes the collective responsibility of all components. This means that the real chaos is a decline in elections is a progress of democracy, because it is a shared responsibility, not because of state hegemony as happened to the previous regime. Therefore, various problems that occurred in the electoral system in the period 2005-2007 based on the regime Shrimp No. 32/2004; 2008-2013 period based on Shrimp Regime No. 12/2008, Shrimp Law Number 22 Year 2007, Shrimp Law Number 15 Year 2011 and period of 2015 based on Shrimp Regime No. 1 of 2015 as amended by Shrimp Law Number 8 of 2015, the important thing that concerns and the responsibility of both the government and the organizers (KPU) and all elements of the nation is, to ensure that the electoral system that has been declining so far, the elections 2015 together become a necessity and important momentum to organize the system Pilkada in Indonesia to be more qualified and zero conflict. This is especially important, considering that the 2015 Pilkada will be the next model 
of elections as the next Pilkada 2015 will be the first stage that will determine the next phase of Pilkada from the three stages of the local elections to be held until 2027.

\section{Direct Election and Strengthening Democracy in Indonesian State System}

One of the forms and mechanisms of democracy in the regions in the Indonesian state administration system is the direct election of regional heads (Pilkada). Pilkada is a means of manifestation of sovereignty and affirmation that voters are people in the region. Pilkada also has four important functions in local governance. First, choose the head of the region in accordance with the will of the people in the region. Secondly, through Pilkada it is hoped that the choice of people in the region will be based on the vision and mission and the program and the quality and integrity of candidates for regional heads, which will determine the success of local governance in the Indonesian state administration system. Thirdly, Pilkada is a means of accountability as well as a means of public evaluation and political control of a regional head and a supporting political force.
Thus, Pilkada is one of the pillars of democracy as a manifestation and strengthening of people's sovereignty in order to produce democratic government to elect a capable, legitimate and acceptable provincial leadership, so that it is hoped that the government can get strong support from the people, able to transform thought and idea into government programs that are oriented towards people's welfare and acceptable to all levels of society. To realize these ideals, it takes effort from all components of the nation to maintain the quality of Pilkada in order to become a substantive and highintegrity Pilkada.

The political direction of the Pilkada law above can only be realized by all stakeholders and all components of the nation if they understand and support the implementation of Pilkada according to the rules of law and respect the political rights of every citizen so that we are aware of efforts to improve the quality of the implementation of Pilkada, so that quality results are part of the process of strengthening democracy and bringing about a more effective and efficient governance. Therefore, direct and 
simultaneous elections on December 9 in 269 autonomous regions constitute a major legal event in the administration and administration of Indonesia. The government realizes that we must reorganize the mechanism, fix the regulation, and build the integrity and conduct of elections, political parties and candidate pairs so that Pilkada can be organized not only from the procedural aspect but much deeper than that is to build a more substantive elections, integrity, safe, smooth, fairness took place and elected regional head and deputy head of the region that is able to prosper the people and promote the region. In this connection, the steps to improve Pilkada in the future also can not be separated from the improvement of the electoral system and electoral process.

In addition, organizational selforganization or independent organizational structuring and awareness-raising of election participants and citizens is required to avoid trapping in the game and pragmatism of power that is detrimental to the interests of the nation and state. The nature of independence or independent is very necessary because in essence the implementation of Pilkada simultaneously attached both to the institutional and functions that run. In addition, the independence of election organizers must also be reflected in the implementation of their duties and responsibilities. Election organizers, both provincial Election Commission (KPU) and Regency / Municipal KPU and Bawaslu and Panwaslu, must be independent in carrying out their respective duties, in accordance with the laws and regulations.

The process of Pilkada simultaneously both now and in the future, we want the improvement of democratic quality that leads to the realization of substantial democracy, including local democracy. One of the efforts that must be done is to improve the quality, professionalism, and independence of Pilkada organizers so that Pilkada that fulfill the principle of luber and jurdil can be held. Thus, the electoral mechanism of elections simultaneously, has prospects and benefits that can be obtained in strengthening the state administration system in Indonesia, including strengthening the governance system in the region. 


\section{Concurrent \\ Consolidation \\ Democracy System}

Moving from the prospect of simultaneous Pilkada and the dynamics of democracy and governance development (read: constitution) as mentioned above, it is hoped that the role of KPU as the organizer of the Regional Head Election must be ready to always stand up to work independently, professionally, impartially, objectively, transparently, accountably and with integrity. Thus, the current and future election organizers (including elections) must be constructed as the fourth branch of state power as a branch of electoral power in addition to the executive power, legislative and judicial branches power). This fourth power branch should be given full power to organize and administer everything concerning the administration of elections, (ii) the administration of election participants, including (iii) the party, the formation, the freezing and the dissolution. And other matters relating to the election as a unitary institution of the election organizers that are national, fixed, and independent. For example, the dissolution of political parties by the Constitutional Court, it is better that the legal standing to file an application is granted to the Election Supervisory Board (Bawaslu) or the General Election Commission (KPU), not to the government as is the current arrangement. On the contrary, because of its very important position, it is not haphazard to be appointed or elected as commissioner of this election organizer. As an election organizer in addition to carrying out the duty of the state is also expected a commissioner is a statesman who has high moral integrity. Thus, it is hoped that the prospect of future elections in Indonesia will grow better over time than is a consolidation effort against Pancasila democracy system in the Indonesian state administration system also keeps Pancasila democracy as the rule of election law and the only model democracy that must be developed in the context of the dynamics of democracy in the state administration in Indonesia. Given since the reform era of Indonesia, the meaning of Pancasila is almost forgotten in the life of nation, society and state, even to mention the word Pancasila alone, it seems almost gone from the minds of this nation. In fact, Pancasila is one of the unique cultural roots of the nation 
that has lived and rooted in the reality of the Indonesian people since centuries.

Therefore, through the general elections it is also an important momentum to re-establish the basic values of Pancasila as the root of democratic culture in Indonesia to build and strengthen a more democratic political system and state administration based on Pancasila values. This is because the basic values of "Pancasila democracy" are democratic models whose essence is not shared by other nations in the world. Strengthening the values of Pancasila democracy is a prerequisite in strengthening local governance systems. The neglect of the Pancasil's democratic values of pancasila will never solve the electoral problem in Indonesia comprehensively from time to time. Improvements in the national electoral system and ignoring the local electoral system will never be effective in solving the problems and prospects of elections simultaneously in Indonesia.

The implementation of a concurrent voting system in both the electoral stages of 2015 elections, as well as the legislative and presidential elections beginning in 2019 provides momentum and good reasons to consolidate the policy of Indonesia's electoral system in the future. The consolidation of the policy needs to be directed for the purpose of consolidating into a more efficient and effective Pancasila democratic system in creating a strong, effective, but accountable and integrity system of governance. More specifically, the consolidation of the electoral system will contribute to a healthier and more credible Indonesian democratic system in the future, which not only rests on the principles of democracy and rule of law, but also of integrity as it is made aware of the principles of ' rule of ethics' and the 'rule of electoral ethics' standards. Therefore, the integrity of elections requires the awareness of all parties to submit to the principles of law and ethics simultaneously. Of course, to begin with, we must prioritize the integrity of election organizers. That's why we build the integrity system of election organizers by establishing an Electoral Organizing Council (DKPP) that serves as the first ethical justice institution in modern history. It is our hope that future elections in Indonesia will grow better 
over time, not only by the 'rule of electoral law' but also by the standards of 'rule of electoral ethics'.

\section{CONCLUSION}

Based on all description above, we can draw some conclusions as follows:

1. That one of the problems in the implementation of the policy of political decentralization has resulted in high political dynamics in the period 2005-2017, where the implementation of the Pilkada brought negative implications on the one hand, namely bringing the potential for the absence of effective and accountable regional administration; the occurrence of horizontal conflicts; people are trapped in money politics in choosing a candidate for regional head and the most crucial is politicization in bureaucratic position at every turn of regional leadership.

2. The ideal future Pilkada format is to re-position Pilkada consistently in the configuration of the Pancasila democratic system in the life of the nation and state. Therefore, the Pilkada is simultaneously meant to strengthen the governance of local government system, also intended to strengthen the values of Pancasila democracy at the local level; giving birth to regional governments capable of creating accountability and effectiveness of local governance, equality of citizens' rights in policing which in turn strengthens Pancasila democracy at the national level; the creation of the effectiveness and efficiency of the state budget and the reestablishment of Pancasila democracy values in the life of the nation and the state to build a more dignified Indonesia.

3. That the General Election simultaneously becomes an important momentum to re-establish the basic values of Pancasila as the root of democratic culture in Indonesia to build a more democratic political and administrative system based on Pancasila values. This is because the basic values of "Pancasila democracy" are democratic models whose essence is not shared by other nations in the world.

4. Therefore, in the context of the development of Indonesian democracy in the future through simultaneous elections it is necessary to strengthen the values of democracy Pancasila is a prerequisite and a necessity in strengthening local democratic system (local government) in the Indonesian state administration system. The 
Papua Law Journal ø Volume 2 Issue 1, November 2017

neglect of the Pancasila democratic values of a piece of food will never solve the electoral problem in Indonesia comprehensively from time to time. Improvements in one electoral system in both the legislative and presidential elections and the neglect of the regional head electoral system will never effectively complete the electoral system in the state administration system in Indonesia.

\section{BIBLIOGRAPHY}

\section{Books:}

Bayu Dwi Anggono, (2014)., Perkembangan Pembentukan Undang-Undang di Indonesia, Jakarta, Konstitusi Press.

Clinton Rossiter, Parties and Party Politics in Amerika, Ithaca, NY: Cornell University Press, 1960, page.1. Lihat juga Richard S. Katz dan William Crotty, Hand Book of Party Politics, London: SAGE Publications, 2006.

Hans Kelsen, (1973) General Theory of Law and State, Translated By Anders Wedberg. New York: Russel\&Russel, 1973.

Jenedjri M. Gaffar, (2012) Politik Hukum Pemilu, Cetakan Pertama, Penerbit Konstitusi Press, Jakarta, .
Jimly Asshiddiqie,

(2006)

Kemerdekaan

Berserikat

Pembubaran Partai Politik dan

Mahkamah Konstitusi, Cetakan

Ketiga, Penerbit Konstitusi Press,

Jakarta.

John Locke, (2001) Two Treaties of

Civil Government, dalam MDA

Freeman, Introduction to

Jurisprudence, seventh ED,

(London: Sweet \& Maxwell Ltd.

K.C. Wheare, (2003) KonstitusiKonstitusi Modern, Cetakan Pertama, Penerbit Pustaka Eureka, Surabaya.

Mirian Budiardjo, (2000) Pengantar Ilmu Politik, Gramedia, Jakarta.

Saifudin, (2009) Partispasi Publik dalam Pembentukan Peraturan Perundang-undangan, Yogyakarta, FH UII Press.

VCRAC Crabbe, (1994) Legislative Drafting. London: Cavendish Publishing Limited.

Yuliandri, (2009) Asas-Asas Pembentukan Peraturan Perundang-undangan yang Baik, Gagasan Pembentukan UndangUndang Berkelanjutan, Jakarta, RajaGrafindo Persada. 
Papua Law Journal @ Volume 2 Issue 1, November 2017

Yves and Andrew Knapp, (1998)

Article:

Governmental and Politics in

Simanjuntak Josner., Kemandirian

Western Europe: Britain, France,

Lembaga Penyelenggara

Italy, Germany, Third Edition,

Pemilihan Umum di

Oxford University Press.

Indonesia.,Papua Law Journal

\section{Magazines:}

Majalah Suara KPU, “Agar Kampanye Tak Mengalami Distorsi”, Edisi II, Volume 1 Issue 1 November 2016, Fakultas Hukum Universitas Cenderawasih Papua. Maret-April 2015. 